\title{
Morphophonemic Process in Javanese
}

\author{
Surana \\ Universitas Negeri Surabaya \\ Surabaya, Indonesia \\ surana@unesa.ac.id
}

\author{
Murdiyanto \\ Universitas Negeri Surabaya \\ Surabaya, Indonesia \\ murdiyanto@unesa.ac.id
}

\begin{abstract}
Absract-Recently, underlying on the background, the language problem handling in grammar, particularly the morphophonemic process, is scarcely sufficient. The study would like to analyze the morphology issue by Thomas, $P$ (1994). The study aims to discuss the research questions encompassing: (1) How does the morphophonemic process occur in Javanese?; (2) How is the evident manifestation of the process in Javanese? Regarding to the methodology, the strategy employed comprises three stages namely data provision, data analysis and data analysis exposure. The employed method would be conformed to the characteristics of data, questions, and purposes of the study along with the Lia Litosseliti contextual method in 2010. To sum up, according to the description and analysis of data, the morphemic process emerges two possibilities which enable to cause the phonemic occasion existing and absent [1]. The first one is called as morphophonemic process, while the second one is the regular morphemic process. Morphophonemic process proceeds a simpilation of the morphemic process and phonemic phenomena, including the insertion, deletion, assimilation, and alteration of phonemes. Additionally, those phonemic occurrences could integrate each other.
\end{abstract}

Keywords-morphophonemic; javanese; morphemic; phonemic.

\section{INTRODUCTION}

Morphophonemic system is a set of rule in language which associates phonological and grammatical system [2], [3], [4]. While phonology encompasses phoneme and any phonemic phenomena, grammar would tend to dissect morphemes, word base, into larger units [5]. In particular way, morphophonemic system tends to break the word down into morphemes and phonemes as they both have interplay relation [6]. It comes up as a result of the merging by morphemes based on the sound $[7] \&[8]$.

Similarly, the morphemic process in Javanese occasionally causes phonemic occurrence in which the interplay correlation later on is called as morphophonemic process [9]. Moreover, based on the study, the morphophonemic rule specifically works on affixation processes [10]. The phenomena consist of the insertion, deletion, assimilation, and alteration of phonemes. Additionally, those phonemic occurrences apparently could integrate each other [11]\&[12].

\section{METHODS}

The theory underlying on the study is the one perceiving a language from form aspect. The study is conducted through three stages namely data provision, data analysis and data analysis exposure. The employed method would be conformed to the characteristics of data, questions, and purposes of the study along with the contextual method [13].

\section{DISCUSSION}

\section{A. The Insertion}

Phonemes which frequently appear because of word formation in Javanese are $/ \mathrm{n} /, / \mathrm{y} /$ and $/ \mathrm{w} /$.

- The Insertion of Nasal Phoneme /n/

The outset of nasal phoneme / $\mathrm{n} /$ happens to the word formation from base, ended with vocal phoneme /e/ combined with suffix $\{-e n\}$. It can be illustrated by the following data.

$$
\begin{aligned}
& \{\text { gawe }\}+\{\text {-en }\}-\text { - } \text { gawenen // gawen } \mathrm{n} / / \\
& \text { make.' (command) } \\
& \{\text { sate }\}+\{- \text { en }\} \quad-\ldots \text { satenen // saten } \mathrm{n} / / \\
& \text { 'grilled it.' } \\
& \{\text { pepe }\}+\{\text {-en }\} \quad-\text { - > pepenen // pepen } \mathrm{n} / / \text { 'dry } \\
& \text { it.' }
\end{aligned}
$$

- The Insertion of Nasal Phoneme /y/

Nasal phoneme / $y /$ emerges on the formation of verb from base, ended by vocal phoneme /e/ combined with suffix $\{-\mathrm{a}\}$. The process is being described by the examples bellow.

$$
\begin{aligned}
& \{\mathrm{N}-\}+\{\text { gawe }\}+\{-\mathrm{a}\}, \quad-\quad->\text { nggawea // } \\
& \text { ngawey // 'make it.' (command) } \\
& \{\mathrm{N}-\}+\{\text { prene }\}+\{-\mathrm{a}\} \\
& \text { 'offer it (to someone).' (command) } \\
& \{\mathrm{N}-\}+\{\text { sate }\}+\{-\mathrm{a}\} \\
& \text { 'make a plate of satay.' (command) }
\end{aligned}
$$

- The Insertion of Semi-Vocal Phoneme /w/

Semi-vocal phoneme /w/ appears on the formation of verb from base, ended by vocal phoneme /o/ combined with suffix $\{-\mathrm{a}\}$. The following examples enable to assist the process. 
$\{\mathrm{N}-\}+\{$ soto $\}+\{-\mathrm{a}\}$
'make a bowl of soto.' (command)

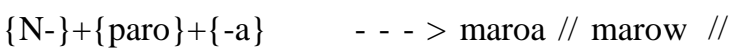
'divide it into two' (command)

$\{\mathrm{N}-\}+\{$ conto $\}+\{-\mathrm{a}\} \quad--->$ nyontoa // nontow // 'imitate (from something)' (command)

\section{B. The Deletion}

The phoneme deletion of word formation in Javanese enables to cause not only the phonemic occasion without another phonemic phenomena, but also with the omission and position shift. These two types are:

- The Phoneme Deletion

The omission of the phoneme in the word formation in Javanese is predominantly occurs to phoneme $/ \mathrm{h} /$. On the word formation related to a word base possessing vocal /a/ combined with consonant $/ \mathrm{h} /$ ending, the $/ \mathrm{h} /$ would be omitted into $\{\mathrm{e}\}$. It can be spelled out as follows.

$$
\begin{aligned}
& \begin{array}{l}
\text { omah }\}+\{-\mathrm{e}\} \\
\text { house' }
\end{array} \\
& \begin{array}{l}
\text { susah }\}+\{-\mathrm{e}\} \\
\text { hardship' }
\end{array}
\end{aligned}
$$

- The Deletion with the Shift of Phoneme

The omission and the shift of phoneme position happens to the formation of verb with prefix $\{-\mathrm{ke}\}$ and ambifix possessing prefix $\{\mathrm{ke}-\}$ with vocal /a/ initially on the word base. On the prefix $\{\mathrm{ke}-\}$, phoneme / / would be omitted and the vocal /a/ would be shifted forward like the examples below.

$$
\begin{aligned}
& \{\text { ke- }\}+\{\text { adhem }\}+\{\text {-en }\} \quad-\quad-\quad-\quad> \\
& \text { cold' } \\
& \text { kadhemen // } \mathrm{kad} \mathrm{mm} \mathrm{n} / / \text { 'being cold/ 'too } \\
& \{\text { ke- }\}+\{\text { abang }\} \quad-\ldots \text { kabang // kaban // } \\
& \text { 'get any red color stain' }
\end{aligned}
$$

\section{The Assimilation of Phoneme}

The phoneme assimilation of word formation in Javanese could be executed in these three following ways.

- Voiceless Consonant and Semi-Vocal/w/

Phoneme /c/ as the initial one in base would be assimilated if it merges with prefix $/ \mathrm{N}-/$ described as follows.

$$
\begin{aligned}
& \{\mathrm{N}-\}+\{\text { cathet }\}_{--.-\rightarrow} \text { nyathet } / / \text { ña ət// 'take } \\
& \text { note' } \\
& \{\mathrm{N}-\}+\{\text { cukur }\}--.-->\text { nyancang //ñukUr// 'shave' } \\
& \{\mathrm{N}-\}+\{\text { conto }\}---\rightarrow \quad \text { nyonto //ñonto// } \\
& \text { 'immitate' }
\end{aligned}
$$

The assimilation of those phonemes is due to the different features [+voice] on /N/ and [-voice] on /c/, while the other distinctive features take role as supportive factors. The reasone why the study puts nasal $/ \mathrm{n} /$ as the choice is because it looks for the feature [+palatal] which is similar with feature of phoneme /c/ to phoneme $/ \mathrm{N} /$.

- The Combination of Suffixation $\{-a n\}$ and Word Base ended with Phonemes /o/ and /u/

The assimilation of phoneme /o/ and /a/ to be / / / takes place on the formation of the word with suffix $\{-$ an $\}$ and the base with $/ \mathrm{o} /$ ending such as the data below.

$$
\begin{aligned}
& \{\text { sepatu }\}+\{- \text { an }\}----\rightarrow \text { sepaton //səpaton// 'wear } \\
& \text { shoes' } \\
& \{\text { laku }\}+\{- \text { an }\} \quad-\cdots \quad \text { lakon //lakon// } \\
& \text { 'trip/journey' } \\
& \{\text { guyu }\}+\{- \text { an }\}----\rightarrow \text { guyon //guysn// 'joke' }
\end{aligned}
$$

In accordance with the feature belonging to each phoneme, the study can examine that the cause of the assimilation is due to the difference in height and pattern between $/ \mathrm{u} /$ and $/ \mathrm{a} /$. The height of $/ \mathrm{u} /$ is [3high] and of $/ a /$ is [1high]. The pattern of $/ \mathrm{u} /$ is [-close] and of $/ \mathrm{a} /$ is [+open]. The result would be $/ \mathrm{J} /$, since the assembly of both phonemes needs the vocal which has features comprising [2high], [+back], and [-tense].

Besides, the formation of base which has /o/ ending combined with suffix $\{-$ an $\}$ undergoes the assimilation between $/ \mathrm{O} /$ and $/ \mathrm{a} /$ into $/ \mathrm{J} /$ as follows.

$$
\begin{aligned}
& \{\text { loro }\}+\{-\mathrm{an}\}-\cdots \quad \text { loron } / / \mathrm{l} \supset \mathrm{r} \supset \mathrm{n} / / \text { 'consists of } \\
& \text { two (people/things)' } \\
& \begin{array}{l}
\{\text { paro }\}+\{- \text { an }\}-\cdots-\cdots \text { paron } / / \text { paron } / / \quad \text { 'divided } \\
\text { into half' }
\end{array} \\
& \{\text { pindho }\}+\{- \text { an }\}--\rightarrow \text { pindhon } \quad / / \text { pin } \supset \text { n } / / \\
& \text { 'twice/two times' }
\end{aligned}
$$

Based on the features of each phoneme, the study examines that the cause of the occurence is the distinction on the height and pattern of both $/ \mathrm{o} /$ and $/ \mathrm{a} /$. The height of $/ \mathrm{o} /$ is is [2high] and of /a/ is [1high]. The pattern of $/ \mathrm{o} /$ is [-close] and of $/ \mathrm{a} /$ is [+open]. The yield of $/ \mathrm{J} /$ is due to the assembly of both phonemes which requires vocal phoneme which is [2high], [+back], and [-tense].

- The Word Formation by Prefix $\{$ ke- $\}$ and Ambifix with Prefix $\{$ ke- $\}$, which Evokes Assimilation 
The word formation of prefix $\{\mathrm{ke}-\}$ and ambifix with prefix $\{\mathrm{ke}-\}$ which evokes assimilation could be illustrated below.

$$
\begin{aligned}
& \{\mathrm{ke}-\}+\{\text { ulu }\} \\
& \text { swallowed up' }
\end{aligned} \quad-\cdots, \text { kolu } / / \mathrm{kolu} / / \quad \text { ' }
$$

Built upon the features, the study examines that the cause of the occurrence is the differentiation on the height, tension and pattern of both $/ \mathrm{a} / \mathrm{dan} / \mathrm{u} /$. The height of $/ \partial /$ is [2high] and of $/ \mathrm{u} /$ is [3high]. The tense of $/ \partial /$ is [-tense] and of $/ \mathrm{u} /$ [+tense]. The pattern of $/ \partial /$ is [-close] and of $/ \mathrm{u} /$ is [+open]. The utterance position of $/ \partial /$ is [-close] dan $/ \mathrm{u} /$ [+close]. The yield of $/ \mathrm{J} /$ is due to the assembly of both phonemes which requires vocal phoneme which is [-velar], [-back], and [-tense].

$$
\begin{aligned}
& \{\text { ke- }\}+\{\text { ili }\} \quad-\cdots-->\quad \text { keli } \quad / / \mathrm{kEli} / / \\
& \text { 'drifted' }
\end{aligned}
$$

In accordance with the features belonging to each phoneme above, the study can examine that the cause of the assimilation is due to the difference in all features between /a/ and /i/, yet the manifestation of /E/ is evoked by the similarity of both phonemes.

$$
\begin{aligned}
& \{\text { ke- }\}+\{\text { eling }\}+\{\text {-an }\} \\
& / / \text { kElingan } / / \text { 'reminded' }
\end{aligned}
$$

Based on the features of each phoneme in abovementioned data, it indicates that the cause of the occurrence is the distinction on the articulators and tension of /ə/ and /e/. Hence, it requires a vocal phoneme which possesses the same height and position, namely /E/.

$$
\begin{aligned}
& \{\text { ke }-\}+\{\text { ilang }\}+\{- \text { an }\} \\
& \text { //kElanyan } / / \text { lose }
\end{aligned}
$$

According to the features of data, it exhibits that the cause of the assimilation is the difference on the articulators and tension of /ə/ and /i/. Hence, it requires a vocal phoneme which possesses the same height and position, namely /E/. Therefore, it uses a vocal phoneme with the same height and position, namely /e/.

\section{$\{$ ke- $\}+\{$ amba $\}+\{-$ an $\}-\cdots>$ kamban \\ //kamban// 'overly wide'}

In accordance with the words above, the analysis obtains that the assimilation happens because the phonemes / $/ 2 /$ and $/ /$ have many similarities in features at most but the only difference takes place on the pattern. Hence, it requires $/ a /$ as a vocal phoneme holding overly different features embracing tension, utterance position, height and pattern.

\section{The Alteration of Phoneme}

Regarding word formation in Javanese, there could be a possibility of a change of phoneme without any phonemic occurrences formerly mentioned and discussed i.e. phonemic occurrences without other phonemic occasion, the change of phoneme therewith the position shift, the alteration and assimilation of phoneme, the alteration and the insertion of phoneme, and the alteration, reduplication, and position shift of phoneme. Beside those phonemic phenomena, there is phonemic change followed by insertion, reduplication, and position shift of phoneme.

However, the alternative change of phoneme / / into /a/ on prefix $\{k a-\},\{a-\},\{s a-\},\{$ ma- $\},\{$ pa- $\},\{p a N-\}$, and $\{$ pra- $\}$ in the merging involving thorough bases. Moreover, there are also the alteration of / / into /o/, and the change vocal phoneme of reduplicated syllables in the form of "dwipurwa" into //. Besides, there is an alteration on adjective modification to be comparative level.

$$
\begin{aligned}
& \{\text { ka- }\}+\{\text { balang }\}-->\text { kabalang // kabalay// 'thrown' } \\
& \{\text { a- }\}+\{\text { klambi }\} \quad-->\text { aklambi // aklambi// 'wearing } \\
& \text { clothes' }
\end{aligned}
$$

$$
\{\text { sa- }\}+\{\text { dina }\} \quad--->\text { sataun // sataUn// 'a/one year' }
$$

\section{CONCLUSION}

To sum up, according to the description and analysis of data, morphophonemic process in Javanese word formation proceeds a simpilation of the morphemic process and phonemic phenomena, including the insertion, deletion, assimilation, and alteration of phonemes. Additionally, those phonemic occurrences could integrate each other.

\section{REFERENCES}

[1] D.Minanda and A. Salsabila, Morphophonemic $\{$ ber- $\}$ in Indonesian Language. Depok, pp. 56-58, 2017.

[2] U. Ekerete Josiah and J. Charles Udoudom, "Morphophonemic Analysis of Inflectional Morphemes in English and Ibibio Nouns: Implications for Linguistic Studies," Toronto., vol. 1, pp. 72-81, April 2012.

[3] F. P. Dinneen, An Introduction to General Linguistics. London: Holt, Rinehart and Winston, Inc., 1966.

[4] L. Nguyen Tai, "The Morphophonemics of English", unpublished.

[5] H. A. Gleason, An Introduction to Descriptive Linguistics. U.S.A.. Holt, Rinehart and Winston, Inc., 1969.

[6] S. Murat Oztaner, "A Word Grammar of Turkish with Morphophonemic Rules," M.Sc.Thesis, Dept. of Computer Engineering, The Middle East Technical University, 1996.

[7] D. A. W. Nurhayati, "Morphological and Morphophonemic Process of Alay Variation," Surakarta., vol. 12, pp. 59-70, Maret 2015.

[8] J.D. Parera, Morfologi. Jakarta: Gramedia, 1990.

[9] N. Paiman, N. T. Yap, and M. Y. Chan, "Effectiveness of morphemic Analysis of Graeco-Latin Word Parts as a Vocabulary Learning Strategy among ESL Learners," Selangor., vol. 21, no.2, pp. 31-45, 2015.

[10] V. Fromkin and R. Rodman, An Introduction to Language. London: Holt, Rinehart and Winston Inc., 1983.

[11] K. Chandra, "Morpho Phonemic Analysis of Grammatical Forms in the North Western Kauravi Hindi as Represented by the Spoken Tongue Of Shahabad Markands District Karnal Kuruksetra Region Panjab,” 2016. 
[12] F. Pisceldo, R. Mahendra, R, Manurung and I W. Arka, "A Two-Level Morphological Analyser for the Indonesian Language", unpublished.

[13] L. Litosseliti, Research Methods in Linguistics. India: MPG Books Group, 2010. 